DOI: http://dx.doi.org/10.30684/etj.37.4C.3

The First International Conference of Engineering Education ( ${ }^{\text {st }}$ ICEE 2019), Iraq, Baghdad,

\author{
9-10 January 2019
}

\section{Nazhat S. AbdulRazak \\ Electro-mechanical \\ Engineering, University of \\ Technology, Baghdad, Iraq drnazhatsaeed2016@gmail.com}

\section{Mariam A. Ali \\ Computer Science Department, University of Technology, \\ Baghdad, Iraq \\ mariammerjan25@gmail.com}

Received on: $15 / 11 / 2018$

Accepted on: 10/01/2019

Published online: 25/12/2019

\title{
Challenges of Implementation E-Learning Platforms in Iraqi Universities
}

Abstract- The great development in the field of information and communication technology (ICT) moved the education reality to a new horizon, where the internet touches almost all aspects of digital learning, we are currently experiencing the existence of electronic platforms in large extent, especially in the field of electronic learning (E-learning), The existence of these platforms stems from the importance of education in general and the importance of transferring the educational process to electronic areas to facilitate learning, in particular, This research aims to target the problems experienced by e-learning in Iraq and offer some recommendations that may contribute to reducing this delay to promote educational reality. An electronic questionnaire was published for students and teaching staff, in which 30 questions was asked. The number of samples participating in the questionnaire was 100 Professors, students, and teachers. Results of the questionnaire showed that they have fully sentient of the essential implementation of electronic learning and its delay reasons.

Keywords-information and communication technology (ICT), digital learning, electronic platforms, E-learning, educational reality.

How to cite this article : N.S. AbdulRazak and M.A. Ali, "Challenges of Implementation E-Learning Platforms in Iraqi Universities," Engineering and Technology Journal, Vol. 37, Part C, No. 4, pp. 400-406, 2919.

\section{Introduction}

In the digital age we live in, almost everything is developed and renewable and is changing rapidly. With every moment, a new idea is produced and new electronic applications are introduced to facilitate life on the human race. Among these aspects, which has been affected in information technology is education. It moved from being traditional to electronic to intelligent. We do not know to this moment where the horizon of education will ends also the Internet had a great impact on education, thanks to this technology students can learn without limits to time and space. In the meantime, when the rest of the world was developing and changing. Iraq was lagging behind. There were several reasons for its delay. Today, we find hundreds of researches to make education more advanced than it was and to make Iraq promote the reality of education. This research highlights the importance of e-learning and its history in the rest of the world in general and in Iraq in particular and looks for obstacles direct the delay of Iraq to implement electronic learning in its educational institutions. We also include questionnaires and presented several recommendations to reduce this delay.

\section{Research Problem}

The importance of this research emerged from the importance of e-learning and its great role in the development of the educational process at the present time and because of this importance, most universities around the world include this technology as an integral part of the education process because it is breaking the barrier of space and time. In the era of modernity, Iraq remains a spectator in front of the technological progress that has taken place in education, while the other countries, in general, have been racing to develop their education and create new horizons for their reality. Iraq, on the other hand, continues using traditional methods of education. In this sense, it was necessary to highlight and draw attention to this problem and to make Iraq cope with the age of modernity that we live in today.

\section{Study Limitation}

1) Time limits: The research was studied in 2019.

2) Spatial limits: Technology University, Electromechanical Engineering Department, Baghdad, Iraq.

3) Objective limits: E-learning, its advantages, and reasons for the delay of its implementation in Iraq. 
4) Specific limits: The study is limited to Iraqi government universities and specifically to University of Technology.

5) Human limits: Students and teaching staff at the University of Technology.

\section{Literature Survey}

Elameer and Idrus studies of the case of Mustansiriyah University show that universities have many problems in terms of safety, technology, management, education, and ethics. Based on pre-surveys on e-learning results, interviews and research show us the need for a complete education system [1].

Arkorful and Abaidoo studied the effectiveness of using e-learning in higher education institutions. It also shows the literature and provides an academic background for research by reviewing the contributions of various researchers and institutions to the concept of e-learning [2].

Al-Azawei et al. highlight the challenges that hinder Iraq from effectively implementing elearning and propose possible solutions to address these challenges; the study proposes a number of solutions to use e-learning methods in a full manner [3].

Ameen and Willis studies the potential and challenges of utilizing online learning in the higher education section of Iraqi institutions according to point view of its learners, the study defines the reasons that made Iraq late in implementing online learning and the scores reveals that students want to utilized a hybrid method of learning by utilizing electronic learning [4].

\section{Definition of E-learning}

Before we define the meaning of e-learning let us first define what learning means: Learning is the process of taking information by individuals to acquiring knowledge through the study of different subjects taught by the supervisor according to the curriculum which is approved by the committee specialized in the educational institution. Therefore, e-learning, on the other hand, offers the utilization of the internet to deliver the information to the educators at different time and place. There are several kinds of research have defined e-learning as follows: Elearning provides free access to the network without considering the time and places restrictions through web technologies in order to promote learning [5]. E-learning systems are web-based software for distributing, tracking, and managing courses over the Internet. They contain features such as chat rooms, whiteboards, discussion forums, polls, quizzes and surveys which allow instructors and students to share course content and communicate online synchronously and asynchronously [6]. Elearning provides delivering of digital data through different devices like mobile phones or laptops to promote methods of learning [7]. Elearning can be considered as the utilization of transmitting and simplifying the curriculum of different courses through the networks [8].

\section{Advantages of E-learning}

The adoption of e-learning especially in the institution of higher education has many benefits to both students and teachers because it focuses primarily on the needs of students also provide the effort on the teacher in delivering of scientific information. The major benefits e-learning as mentioned by Elameer and Idrus are: E-learning can fill the problems of the Iraq institutions, for instance: dealing with inability of the staff in the university in order to make digital curriculum to complement student classroom learning. Also, elearning strengthens student-centered education, address the lack of up-to-date information, and use the latest ICTs to promote student learning [9, $10]$.

Other advantages as mentioned by the authors are:

1) The adoption of e-learning provides the institutions as well as their students or learners the much flexibility of time and place [11].

2) Improve the effectiveness of learning by easily accessing digital data.

3) By using the online forum, it offers abilities to strengthen communications among the students.

4) It is considered an inexpensive way to learn because students don't have to be distanced from their homes and it provides many ways to learn without the need for existing in the same place.

5) It takes into consideration the different abilities of learning of each student, such as many students are more willing to focus on certain parts of the curriculum while some of them are willing to take the entire curriculum.

6) It assists to fill the scarcity of faculty staff, like professors, teachers, laboratory technicians and supervisors [12].

\section{Evolution of E-learning}

Education is undoubtedly the backbone of the cultural advancement of the generations. The education passed through several stages until it reached the desired results so far. Evolution of elearning will be explained as the following: 
1) Traditional learning: in this method where the teaching staff is the only origin of transferring the acquaintance, it is sometimes called direct or formal teaching method.

2) Electronic learning (E-Learning): it is an advanced learning method than ordinary learning by utilize the web to assist distance learning.

3) Blended learning: it integrates traditional classes by utilizing electronic learning method as an auxiliary along with formal learning environment.

4) Mobile learning (M-Learning): it is considered as a competence of electronic-learning methods. In this method educators utilize portable devices like mobile phones along with wireless communications in order to download or uploading electronic contents.

5) Ubiquitous learning (U-Learning): it is a modern learning way that uses a mix of online and mobile learning modes; it is called ubiquitous technology that utilizes ubiquitous devices and environments to learn [13].

\section{E-learning Experiences in the World}

The modern countries have adopted e-learning for many years because of its huge benefits in universities and schools. In the next section, we will explore Western and Arabic experiences of electronic-learning as the following.

\section{Western experiences}

In 1969, the British government established Open University (OU) which collaborated with the BBC to develop university courses and it has aimed from its inception to be open to people, places, methods, and ideas [14]. Malaysia in 1997 launched an intelligent education plan, called a smart school which is carried out by the government [15]. Since 2006, Singapore has launched a smart project that utilized the technology as an essential part to dedicate the education that made a special education environment for eight future Singapore schools [16]. Australia collaborated with IBM and designed a smart, multi-disciplinary studentcentric education system (IBM 2012). Their system links schools, tertiary institutions and workforce training [17]. The Australian partnership along with IBM project in 2012, which creates an intelligent, many directional, and learner-focused education methods that, connects Australian schools, institutions, and workshops to offer proper training. Smart South Korea learning plan in 2012 considers a major educational project system to enhance the infrastructure of Korean education. [18]. In the
USA especially in New York a Smart School commission reported that in 2014 this program integrates the technology role into school's room, this project prepares the learners and enhance their achievements to make them able to participate into the economy of 21 st- century [19]. Finland has also implemented an intelligent learning project, the ongoing learning system solutions in the year of 2011 try to advance 21stcentury education reality [20].

\section{Arabic experiences}

TUNIS (VUT) as a short name of virtual Tunisian university, established in January 2002. It has two main objectives: first to ensure a proportion of courses by e-learning methods for a population of students in continuous increasing number. Second to contribute to the modernization of the education system by the use of the new technologies of information and communication [21]. At KSA, an eLearning section for Training and Resources created in 2002 (GOTEVOT), that made an e-library that offers 50,000 books with 3,000 e-services programs. In 2008, KSA ministry of higher education also produced a program for learning along with Google services that include the participation of more than 1,200 facilities and 20,000 teachers [22]. In 2003 Jordan launched in collaboration with Cisco a program that ensures the part of Jordanian Information and Communication Technology (ICT) provides huge opportunities to enhance the programs of learning in Jordan [23]. In Egypt Arab Open University (AOU) opened in Cairo in 2003 that offers distance learning, e-learning of University of Egypt (EELU) in 2008. It is a privately-owned, non-profit organization that offers distance learning along with the sight of providing international e-learning [24]. In 2012, the United Arab Emirates (UAE) started investing in an intelligent learning method called the Mohammed Bin Rashid Smart Learning Program (MBRSLP) that creates a modern environment for education [25]. Now UAE launching the widest e-learning platform in the Middle East, it's called MADRASA platform, under the umbrella of the global initiatives of Mohammed bin Rashid AlMaktoum, the region's largest regional hope industry and building a better future for humanity.

\section{E-learning Situation in Iraq}

Iraqi institutions are inspired by utilizing electronic learning. Although they have newly started implementing it, the ancient civilizations of our beloved country, like Assyrians, 
Babylonians and the Chaldeans, have been considered the first dawn of history in the world. Their history has been recorded for more than 8,000 years. Iraq was the first leader country [3]. After 2003, as the same case of other parts of our country, Iraqi higher education was concerned with the violence in most provinces. UNESCO reported that from 2003 to 2012, about 500 academics and professors of higher institutions were murdered [26]. Compared with neighboring countries, there are many obstacles that have caused Iraq to abandon e-learning. These include inadequate costs, insecurity, and lack of preparation and reassurance [27]. First Iraqi usage of electronic learning was in 2010; Moodle implemented and utilized through limited sectors of Iraqi universities departments [9]. In 2015, every institutions and university utilized with Moodle [28]. From 2016 till now, there is a great effort and many attempts to make Iraq keep pace with the technological development that was delayed and there are several projects are launched annually to create e-learning platforms to meet the severe shortage in Iraq in the educational institutions in general and these platforms are still doing well, but the universities of Iraq still need to Further development and progress to regain its place among its peers from neighboring countries.

\section{Case Study}

We have targeted the University of Technology as its great history and it is always trying to renew its infrastructure and keep abreast of

Table 1: Results of students' questionnaire technological development and graduated every year students at a high level of efficiency.

An electronic questionnaire was distributed targeting a sample of students and teaching staff from the university, especially in the Department of Electromechanical Engineering.

The number of participants is 100 student, teachers, and academic staff. $51 \%$ were females and $49 \%$ were males. $79 \%$ aged from (18-30) years, $15 \%$ aged from (30-50) years and 6\% were at age (50) years. 93\% studied at the University of Technology and 7\% studded at other universities. The level of qualifications was between $60 \%$ has B.Sc., 23\% have M.Sc., 12\% have Ph.D. and 5\% has other qualifications. $80 \%$ were students and $20 \%$ were teachers. The purpose of this study was to survey the views on e-learning and to identify the obstacles and problems that have made Iraq left behind in the application of e-learning. The first part of the questionnaire included demographic information, including age, educational achievement, and gender, etc. The second part of the questionnaire was about students' views on e-learning. The third section was about the teaching staff's opinion $\mathrm{n}$ elearning. The fourth section was a joint section for students and teaching staff on their opinion of factors affecting the application of e-learning in Iraq. Results are shown below:

\begin{tabular}{|c|c|c|c|c|}
\hline $\begin{array}{l}\text { Question } \\
\text { Number }\end{array}$ & Question & Agreed & Disagreed & Analysis the Results \\
\hline 1. & $\begin{array}{l}\text { Does e-learning raise } \\
\text { students' educational level } \\
\text { and increase their success } \\
\text { rates? }\end{array}$ & $93 \%$ & $7 \%$ & $\begin{array}{l}\text { This is a very positive result that demonstrates the } \\
\text { awareness of the teaching staff of the importance of } \\
\text { e-learning in the advancement of the educational } \\
\text { process and pushes it towards the best and thus } \\
\text { raises success rates among the students. }\end{array}$ \\
\hline 2. & $\begin{array}{l}\text { Does e-learning help } \\
\text { students to adapt } \\
\text { themselves in the learning } \\
\text { process? }\end{array}$ & $96 \%$ & $4 \%$ & $\begin{array}{l}\text { This indicates the importance of e-learning and its } \\
\text { usefulness from the point of view of the teachers. } \\
\text { We must give sufficient confidence to our students. } \\
\text { The students have to rely on themselves also they } \\
\text { can learn how to discipline their time to learn. }\end{array}$ \\
\hline 3. & $\begin{array}{l}\text { Do e-learning platforms } \\
\text { provide facilities for } \\
\text { students with special needs } \\
\text { or students who live in } \\
\text { remote areas? }\end{array}$ & $81 \%$ & $19 \%$ & $\begin{array}{l}\text { This is a good result of the teachers' awareness } \\
\text { about the students with special needs or who lives in } \\
\text { remote areas and how e-learning platforms will help } \\
\text { them solve their problems. }\end{array}$ \\
\hline 4. & $\begin{array}{l}\text { Does e-learning provide } \\
\text { ease of teaching staff in } \\
\text { pursuing student learning? }\end{array}$ & $95 \%$ & $5 \%$ & $\begin{array}{l}\text { Students vary in their cognitive abilities, but through } \\
\text { e-learning, they can repeat the course many times to } \\
\text { understand the lesson and ask their supervisor only } \\
\text { in situations that were difficult for them, therefore, } \\
\text { teacher is able to follow the progress of his students } \\
\text { and only targets the weakness points of their } \\
\text { learning to strength them. }\end{array}$ \\
\hline
\end{tabular}


Table 2: Results of Teachers' questionnaire

\begin{tabular}{|c|c|c|c|c|}
\hline $\begin{array}{l}\text { Question } \\
\text { Number }\end{array}$ & Question & Agreed & Disagreed & Analysis the Results \\
\hline 1. & $\begin{array}{l}\text { Does your department } \\
\text { uses electronic learning } \\
\text { platforms? }\end{array}$ & $46 \%$ & $54 \%$ & $\begin{array}{l}\text { We believe that it is essential that all university departments } \\
\text { must be able to provide e-learning platforms to keep up with } \\
\text { developed universities around the world }\end{array}$ \\
\hline 2. & $\begin{array}{l}\text { Do you think that the use } \\
\text { of e-learning platforms is } \\
\text { easy or difficult? }\end{array}$ & $81 \%$ & $19 \%$ & $\begin{array}{l}\text { This depends on the student and on the breadth of his/her } \\
\text { knowledge of the e-learning platforms and this result is } \\
\text { considered good }\end{array}$ \\
\hline 3. & $\begin{array}{l}\text { Do you prefer a } \\
\text { smartphone or computer in } \\
\text { the usage of e-learning } \\
\text { platforms? }\end{array}$ & $57 \%$ & $43 \%$ & $\begin{array}{l}\text { We suggest providing e-learning platforms suitable for both } \\
\text { smartphone and computers to provide the flexibility of } \\
\text { learning }\end{array}$ \\
\hline 4. & $\begin{array}{l}\text { Does your department } \\
\text { provide you free internet } \\
\text { access? }\end{array}$ & $12 \%$ & $88 \%$ & $\begin{array}{l}\text { This is a disappointing result, because we live in a world } \\
\text { where the internet is dominating over all aspects of life, and } \\
\text { the students need to connect to the Internet all the time to } \\
\text { reach e-learning platforms so they can share educational } \\
\text { materials, ideas, take courses, answer questions and make } \\
\text { discussions. }\end{array}$ \\
\hline 5. & $\begin{array}{l}\text { Does your department } \\
\text { provide you modern } \\
\text { learning methods such as } \\
\text { smart board, data-show, } \\
\text { and others? }\end{array}$ & $45 \%$ & $55 \%$ & $\begin{array}{l}\text { The university has now started to introduce intelligent } \\
\text { teaching methods on the educational process but at a slow } \\
\text { pace. We believe that all students have the right to learn in a } \\
\text { smart and modern way. }\end{array}$ \\
\hline
\end{tabular}

Table 3: Results of both students' and teachers' questionnaire

\begin{tabular}{|c|c|c|c|c|}
\hline $\begin{array}{l}\text { Question } \\
\text { Number }\end{array}$ & Question & Agreed & Disagreed & Analysis the Results \\
\hline 1. & $\begin{array}{l}\text { Do you consider e-learning } \\
\text { an effective way to learn? }\end{array}$ & $64 \%$ & $36 \%$ & $\begin{array}{l}\text { This is positive because it exceeds half the number of } \\
\text { respondents and indicates that of e-learning is an effective } \\
\text { way to learn according to them. }\end{array}$ \\
\hline 2. & $\begin{array}{l}\text { Do you prefer to use } \\
\text { traditional education or e- } \\
\text { learning methods? }\end{array}$ & $92 \%$ & $8 \%$ & $\begin{array}{l}\text { This percentage can be considered good thus its relevance to } \\
\text { the personal opinion of the responders. }\end{array}$ \\
\hline 3. & $\begin{array}{l}\text { Are you facing troubles } \\
\text { while using the e-learning } \\
\text { platforms? }\end{array}$ & $60 \%$ & $40 \%$ & $\begin{array}{l}\text { This is a promising result. But this does not mean that we } \\
\text { neglect the rest who suffer from difficulties while using e- } \\
\text { learning, so universities should take care of this aspect and } \\
\text { provide workshops on how to use e-learning platforms. }\end{array}$ \\
\hline 4. & $\begin{array}{l}\text { Have you ever participated } \\
\text { in seminars or workshops } \\
\text { about e-learning? }\end{array}$ & $41 \%$ & $59 \%$ & $\begin{array}{l}\text { This result is disappointing because this indicates negligence } \\
\text { of spreading awareness of the importance of e-learning by } \\
\text { universities. We must change this reality by conducting } \\
\text { activities and seminars on the importance of e-learning and } \\
\text { provide proper training for teaching staff and students to } \\
\text { guide them on the right path. }\end{array}$ \\
\hline 5. & $\begin{array}{l}\text { Do you consider Iraq is at a } \\
\text { late stage in the application } \\
\text { of e-learning? }\end{array}$ & $78 \%$ & $22 \%$ & $\begin{array}{l}\text { With the advent of the Internet, the impact of development } \\
\text { has come from our reality to keep our country with pace of } \\
\text { technological progress in the rest of the world so e-learning } \\
\text { must be comprehensive and covers all the Iraqi universities. }\end{array}$ \\
\hline 6. & $\begin{array}{l}\text { How does the English } \\
\text { language affect the } \\
\text { understanding and use of e- } \\
\text { learning systems? }\end{array}$ & $88 \%$ & $12 \%$ & $\begin{array}{l}\text { English language is important to use e-learning systems, so } \\
\text { universities must provide free English language courses to all } \\
\text { of the student and faculty member. }\end{array}$ \\
\hline 7. & $\begin{array}{l}\text { Do you think that the } \\
\text { Intellectual property rights } \\
\text { are important for the } \\
\text { application of e-learning in } \\
\text { Iraq? }\end{array}$ & $87 \%$ & $13 \%$ & $\begin{array}{l}\text { We find that there is a need to protect intellectual rights and } \\
\text { provide penalties against scientific theft. Because of this, } \\
\text { there is no room for creativity and no incentive for } \\
\text { innovation, therefore the protection of intellectual rights is an } \\
\text { urgent need. }\end{array}$ \\
\hline
\end{tabular}




\section{Conclusion}

This research casts the light on obstacles to the use of e-learning techniques in teaching and learning for academic members and undergraduates at public universities in Iraq. Also this research put forward several views on how to reduce the delay of Iraqi universities in the application of e-learning and this does not mean that Iraq cannot keep pace with technological developments in the world, but on the contrary, this is an incentive to start spreading awareness about the importance of e-learning and provide the necessary funding, right training, providing free courses and workshops, protection of intellectual rights against theft, taking care of the infrastructure, providing safety and security and improving the role of the Ministry of Higher Education. Iraq can truly keep pace with modernity because of the percentage of awareness among the students and teaching staff on the importance of this technology and the importance of their inclusion in the educational process.

\section{Acknowledgment}

We thank the University of Technology that gave us the opportunity to make the above mentioned questionnaires that greatly assisted this research, although they may not agree with all of the interpretations/conclusions of this paper.

\section{References}

[1] A. S. Elameer, and R. M. Idrus, "EL AMEER-IDRUS ORBITAL E-EDUCATION FRAMEWORK FOR THE UNIVERSITY OF MUSTANSIRIYAH (MUST)," The Turkish Online Journal of Educational Technology, Vol. 10, No. 4, pp. 9, 2011.

[2] V. Arkorful and N. Abaidoo, "The role of elearning, the advantages and disadvantages of its adoption in Higher Education," International Journal of Education and Research, Vol. 2, No. 12,p p. 14, 2014.

[3] A. Al-Azawei,p p. Parslow, and K. Lundqvist, "Barriers and Opportunities for E-Learning Implementation in Iraq: A Case of Public Universities," The International Review of Research in Open and Distributed Learning, Vol. 17, No. 5, Sep. 2016.

[4] N. Ameen and R. Willis, "The use of e-learning of students in Iraqi universities: potential and challenges," presented at the 8th International Visible Conference on Educational Studies \& Applied Linguistics (VESAL2017), Erbil, Iraq, 2017.

[5] R.C. Clark, R.E. Mayer, "E-Learning and the Science of Instruction,” Wiley, 2011.

[6] Islam, N., \& Azad, N. "Satisfaction and continuance with a learning management system," The
International Journal of Information and Learning Technology, 32(2), 109-123, 2015.

[7] A. Elsaadany and K. Abbas, "Development and implementation of e-learning system in smart educational environment," in 2016 39th International Convention on Information and Communication Technology, Electronics and Microelectronics (MIPRO), pp. 1004-1009, 2016.

[8] F. ENNEB-BenKhaled and M. Maraoui, "Toward a smart E-leaming system (A state of the art)," in 2017 International Conference on Engineering MIS (ICEMIS), pp. 1-7, 2017.

[9] A.S. Elameer, \& R.M. Idrus, "The readiness for an e-learning system in the University of Mustansiriyah (UoMust) Baghdad-Iraq," Malaysian Journal of Educational Technology, 10(2), 31-41, 2010.

[10] A.S. Elameer and R.M. Idrus, "ELAMEERIDRUS ORBITAL E-EDUCATION FRAMEWORK FOR THE UNIVERSITY OF MUSTANSIRIYAH (UOMUST)," The Turkish Online Journal of Educational Technology, Vol. 10, No. 4, p p. 9, 2011.

[11] Smedley, J.K.'Modeling the impact of knowledge management using technology". OR Insight, 23, 233250.2010

[12] V. Arkorful and N. Abaidoo, "The Role of eLearning, the Advantages and Disadvantages of Its Adoption in Higher Education." International Journal of Education and Research, 2, 397-410, 2014.

[13] Z.M. Tahir, H. Haron, and J.K.G. Singh, "Evolution of Learning Environment: A Review of Ubiquitous Learning Paradigm Characteristics," Indonesian Journal of Electrical Engineering and Computer Science, Vol. 11, No. 1, pp. 175-181, 2018.

[14] "History of the Open University | Open University." [Online]. Available: http://www.open.ac.uk/researchprojects/historyofou/.

[15] F.M. Chan, ICT in Malaysian schools: Policy and strategies. ICT in Education, pp. 15-22, 2012.

[16] M.T.A. Hua, Promises and threats: iN2015 Masterplan to pervasive computing in Singapore. Sci. Technol. Soc 17, 1, 37-56, 2012.

[17] IBM, Smart Education, 2012, https://www.ibm.com/smarterplanet/global/files/au_e n_uk_cities_ibm_smarter_education_now.pdf.

[18] J.W. Choi, Y.J. Lee, "The Status of SMART Education in KOREA," World Conference on Educational Multimedia, Hypermedia and Telecommunications, 1, 175-178, 2012.

[19] New York Smart Schools Commission Report, 2014 ,

http://www.governor.ny.gov/sites/governor.ny.gov/file s/archive/ governor_files/SmartSchoolsReport.pdf.

[20] M. Kankaanranta, T. Mäkelä, "Valuation of emerging learning solutions," in World Conference on Educational Multimedia, Hypermedia and Telecommunications, Tampere, Finland, 2014.

[21] "(PDF) the Virtual University of Tunis, Realisations, and Perspectives." [Online]. 
Available:https://www.researchgate.net/publication/23 5760398_The_Virtual_University_of_Tunis_Realisati ons_and_Perspectives.

[22] A.M. Al-Asmari and M.S. Rabb Khan, "Elearning in Saudi Arabia: Past, present, and future," Near and Middle Eastern Journal of Research in Education, No. 2014, p p. 2, Jan. 2014.

[23] "(PDF) Implementing e-learning in the Jordanian Higher Education System: Factors affecting impact," Research Gate. [Online]. Available: https://www.researchgate.net/publication/272942607_I mplementing_e-

learning_in_the_Jordanian_Higher_Education_System _Factors_affecting_impact.

[24] "(PDF) e-Learning in the Egyptian Public Universities: Overview and Future Prospective," ResearchGate. [Online]. Available: https://www.researchgate.net/publication/259483851_ e-

Learning_in_the_Egyptian_Public_UniversitiesOvervi ew_and_Future_Prospective.

[25] “(PDF) Curriculum Development in the United Arab Emirates," ResearchGate. [Online]. Available: https://www.researchgate.net/publication/318723972_ Curriculum_Development_in_the_United_Arab_Emir ates

[26] B. O’Malley, “Education under Attack 2014. Retrieved from http://protectingeducation.org/sites/default/files/docum ents/eua_2014_full_0.pdf, 2014.

[27] N. Matar, Z. Hunaiti, S. Halling, \& S. Matar, "Elearning acceptance and challenges in the Arab Region," In S. Abdallah \& F. Albadri (Eds.), ICT acceptance, investment, and organization: Cultural practices and values in the Arab world (pp. 184-200, 2010. Hershey, PA: Information Science Reference. doi:10.4018/978-1-60960-048-8.ch013.

[28] A. Al-Din, \& K. AlRadhi, "Distance learning/elearning for Iraq: Concept and road map," American Society for Information Science and Technology, 34, 3, 34-37, 2008. 